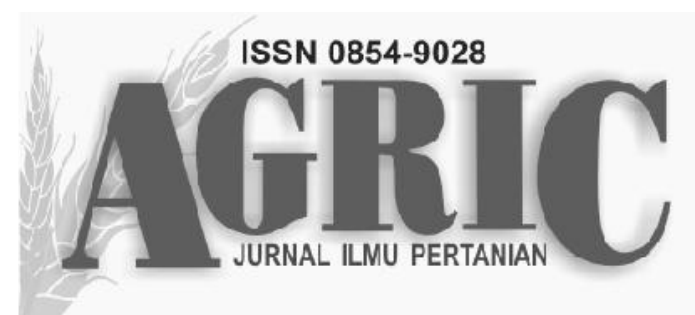

Fakultas Pertanian dan Bisnis Universitas Kristen Satya Wacana Jl. Diponegoro 52-60 SALATIGA 50711 - Telp. 0298-321212 ext 354

email: agric_fpb@yahoo.co.id, website: ejournal.uksw.edu/agric

\title{
PERAN JERAMI PADI DALAM MEMPERBAIKI HASIL GABAH DAN SERAPAN KALIUM DI LAHAN SAWAH TADAH HUJAN DI KABUPATEN PATI, JAWA TENGAH
}

\section{RICE STRAW ROLE IN IMPROVING GRAIN YIELD AND POTASSIUM UPTAKE IN RAINFED LOWLAND RICE AREAS AT PATI, CENTRAL JAVA}

\author{
A. Wihardjaka \\ Balai Penelitian Lingkungan Pertanian \\ Jl. Jakenan km 5 Kotak Pos 5 Jakenan Pati 59182 Jawa Tengah \\ awihardjaka@yahoo.co.id; awihardjaka@gmail.com
}

Diterima 19 Desember 2014, disetujui 2 Maret 2015

\begin{abstract}
As agricultural waste, rice straw could be used to substitute potassium fertilizer in food crops farming system, especially rice crop. The use of rice straw in rainfed lowland areas is not significant to substitute potassium fertilizer which is relatively higher cost. The field experiment was conducted to determine potassium uptake pattern of rainfed lowland rice in light textural Endoaquepts through using straw and inorganic fertilizers. The experiment was arranged using split plot design where rice straw as main plot and potassium fertilizer as subplot. The variable observed was agronomic variable, potassium uptake, exchangeable potassium. The straw incorporation into soil increased the higher exchangeable potassium content in topsoil and also could reduce $K$ losses due to leaching. The peak of $K$ uptake was occurred at panicle initiation growth phase and gradually declined at reproductive growth phase. Interaction between rice straw and potassium fertilization increased significantly grain yield of $0.93-1.39$ t/ha. The increase of potassium rate and its application method did not influence significantly grain yield of Ciherang variety.
\end{abstract}

Keywords: grain yield, potassium uptake, rainfed lowland, rice straw 


\section{PENDAHULUAN}

Indonesia telah mencanangkan pencapaian swasembada pangan terutama beras pada tahun 2016-2017. Swasembada pangan dapat dicapai dengan memanfaatkan lahan sawah beririgasi yang ada dan optimalisasi lahan-lahan sawah suboptimal seperti sawah tadah hujan. Namun tanah sawah tadah hujan, umumnya mempunyai kesuburan rendah dan kahat hara seperti kalium (K) dalam tanah. Pola tanam yang intensif dan penggunaan varietas dengan hasil tinggi menyebabkan deplesi berat $\mathrm{K}$ dalam tanah terutama tanpa pemberian pupuk kalium (Saha et al., 2009)

Keberhasilan tanaman pertanian ditentukan oleh berbagai faktor, antara lain ketersediaan air dan hara-hara esensial bagi tanaman. Kalium sebagai salah satu hara esensial diperlukan tanaman dalam jumlah banyak dan memegang peranan penting dalam proses metabolisme mulai dari prosess fotosintesis, translokasi asimilat hingga pembentukan pati dan protein (Karama et al., 1992), yang pasokannya mempengaruhi pertumbuhan padi (Ranamukhaarachi dan Ratnayake, 2006)

Kekahatan kalium (K) pada tanaman akan menghambat seluruh proses metabolisme, sehingga dapat menurunkan produktivitas tanaman. Tanaman yang kahat $\mathrm{K}$ cenderung cepat menua, pemasakan tidak merata dan kehampaan gabah tinggi, serta rentan terhadap serangan hama dan penyakit (Karama et al., 1992; Suparyono et al., 1992). Gejala kekahatan K pada tanaman padi ditunjukkan dengan tanaman tumbuh kerdil dengan daun lebih kecil, pendek, batang kurang keras, mudah rebah, translokasi karbohidrat terhambat, dan menurunkan serapan hara lainnya (Dobermann dan Fairhurts, 2000).

Kekahatan kalium disebabkan oleh rendahnya kapasitas pasokan K dalam tanah (Saha et al., 2009), pemupukan K tidak cukup, jerami terangkut, masukan $\mathrm{K}$ dari air irigasi rendah, dan tingginya konsentrasi asam-asam organik, $\mathrm{H}_{2} \mathrm{~S}$, dan $\mathrm{Fe}^{2+}$ yang menghambat pertumbuhan akar dan serapan K. Kekahatan K umumnya ditemukan pada tanah dengan kandungan $\mathrm{K}$ rendah terutama tanah yang bertekstur kasar dengan kapasitas tukar kation rendah, dan tanah dengan daya tambat $\mathrm{K}$ rendah, serta tanah yang telah lanjut perkembangannya seperti Ultisol dan Oksisol (Dobermann dan Fairhurts, 2000).

Di ekosistem sawah tadah hujan, kelengasan tanah berfluktuasi selama musim pertanaman. Fluktuasi kondisi tanah silih berganti dari anaerobik ke aerobik mempunyai konsekuensi sangat besar bagi ketersediaan hara dan serapan hara oleh akar tanaman (Wade et al., 1998). Fluktuasi kondisi basah-kering menentukan efektivitas akar dalam menyerap unsur hara. Tanaman menyerap ion $\mathrm{K}$ dalam tanah dalam bentuk dapat ditukar dan larutan tanah, dimana ketersediaan $\mathrm{K}$ bagi tanaman merupakan fungsi besarnya bentuk $\mathrm{K}$ dalam tanah, laju pertukaran, dan tingkat pencucian (Sekhon, 1995).

Menurut Su (1980) dalam De Datta (1981), penyerapan $\mathrm{K}$ pada fase anakan maksimum meningkatkan jumlah malai dan gabah. Bilamana kalium diserap pada fase pembentukan malai, maka akan meningkatkan jumlah malai, gabah, dan bobot gabah. Kalium yang diserap setelah pembentukan malai, maka umumnya dapat meningkatkan bobot gabah. Lebih lanjut dilaporkan Su (1980) dalam De Datta (1981) bahwa tanaman padi memberikan tanggapan positif jika kalium diberikan secara bertahap.

Masukan K mutlak dibutuhkan dalam sistem usahatani tanaman pangan, terutama pada tanahtanah yang ketersediaan kaliumnya rendah. Kalium yang bersumber pada pupuk anorganik umumnya cepat tersedia bagi tanaman, bilamana dikelola secara tepat. Namun dengan semakin tingginya biaya pupuk anorganik terutama $\mathrm{KCl}$ dan petani kurang dapat menjangkaunya, maka jerami dapat digunakan sebagai alternatif penggantinya. Jerami padi mengandung 1,24\% K, sehingga dapat meningkatkan efisiensi penggunaan pupuk K anorganik (Sri Rochayati et al., 1990; Odjak, 1992); Ranamukhaarachi dan Ratnayake, 2006).

Perilaku kalium yang berasal dari pupuk anorganik ataupun pupuk organik tergantung pada kondisi kelengasan tanah, sehingga akan menentukan pola serapan kalium selama pertumbuhan tanaman berlangsung. Oleh karena itu, kegiatan penelitian dilaksanakan dengan tujuan untuk mengetahui pola serapan kalium padi sawah tadah hujan yang 
diberi perlakuan jerami dan pupuk anorganik pada tanah Vertic Endoaquepts bertekstur ringan, dan untuk mendapatkan cara pemberian pupuk kalium yang efektif memberikan hasil gabah optimum.

\section{BAHAN DAN METODE}

Percobaan dilaksanakan di Instalasi Kebun Percobaan Jakenan, Kabupaten Pati, Provinsi Jawa Tengah pada musim kering 2012. Lokasi penelitian terletak pada ketinggian $7 \mathrm{~m} \mathrm{dpl,111^{ \circ } 4 0 ^ { \prime }}$ BT dan $6^{\circ} 45^{\prime}$ LS. Tanah Vertic Endoaquept di tempat penelitian merupakan tanah Inceptisol yang terdapat gejala bidang kilir akibat kembangkerut silih berganti, bertekstur ringan dan kahat kalium. Tanah bereaksi agak masam-masam dengan daya hantar listrik rendah, kandungan bahan organik rendah, KTK dan kandungan K dapat ditukar sangat rendah (Tabel 1). tanam (K3), dan pemberian $50 \mathrm{~kg} \mathrm{~K}$ sebelum tanam $+50 \mathrm{~kg} \mathrm{~K}$ saat $20 \mathrm{hst}(\mathrm{K} 4)$.

Bibit padi varietas Ciherang ditanam pindah setelah berumur 21 hari dengan menggunakan jarak tanam $20 \mathrm{~cm} \times 20 \mathrm{~cm}$ pada petakan-petakan berukuran $4 \mathrm{~m} \times 5 \mathrm{~m}$. Sebelum bibit ditanam, tanah diolah sekali dan diratakan, dibiarkan selama dua minggu. Jerami padi gogorancah diberikan bersamaan dengan pengolahan tanah dengan takaran 5 t/ha berat kering mutlak. Pupuk N sebanyak $120 \mathrm{~kg} \mathrm{~N} /$ ha diberikan tiga tahap, 1/3 N sebelum tanam, $1 / 3 \mathrm{~N}$ saat $20 \mathrm{hst}, 1 / 3 \mathrm{~N}$ saat $35 \mathrm{hst}$. Pupuk P sebanyak $20 \mathrm{~kg}$ P/ha diberikan sekaligus sebelum tanam.

Pemeliharaan tanaman dilakukan secara intensif dengan mempertimbangkan kondisi tanaman di lapangan. Pengendalian gulma dilakukan dua kali

Tabel 1. Analisis sifat fisik dan kimia tanah Endoaquept Jakenan

\begin{tabular}{|c|c|c|}
\hline \multirow{2}{*}{ Sifat tanah } & \multicolumn{2}{|c|}{ Kedalaman tanah $(\mathrm{cm})$} \\
\hline & $0-15$ & $16-30$ \\
\hline $\mathrm{pH}-\mathrm{H}_{2} \mathrm{O}(1: 1)$ & 5,3 & 6,5 \\
\hline Daya hantar listrik (1:1), $\mathrm{dS} \mathrm{m}^{-1}$ & 0,12 & 0,08 \\
\hline C organik $(\%)$ & 0,34 & 0,11 \\
\hline $\mathrm{N}$ total $(\%)$ & 0,04 & 0,02 \\
\hline P terekstrak Bray 1 (ppm P) & 13,00 & 1,70 \\
\hline $\mathrm{K} \mathrm{T} \mathrm{K}\left(\mathrm{cmol} \mathrm{kg}^{-1}\right)$ & 5,49 & 11,67 \\
\hline \multicolumn{3}{|l|}{ Kation dapat ditukar $\left(\mathrm{cmol} \mathrm{kg}^{-1}\right)$} \\
\hline $\mathrm{Ca}$ & 3,97 & 9,97 \\
\hline $\mathrm{Mg}$ & 0,30 & 1,17 \\
\hline $\mathrm{K}$ & 0,04 & 0,08 \\
\hline $\mathrm{Na}$ & 0,11 & 0,40 \\
\hline $\mathrm{Zn}$ tersedia $(\mathrm{ppm})$ & 0,22 & 0,08 \\
\hline \multicolumn{3}{|l|}{ Tekstur tanah (\%) } \\
\hline Pasir & 41 & 23 \\
\hline Debu & 48 & 40 \\
\hline Liat & 11 & 37 \\
\hline
\end{tabular}

Percobaan disusun menggunakan rancangan petak terpisah, diulang tiga kali. Penggunaan jerami padi sebagai petak utama terdiri atas dua aras, yaitu tanpa jerami (J0) dan dengan jerami (J1), sedangkan perlakuan pupuk anorganik sebagai anak petak yang terdiri atas lima aras, yaitu tanpa $\mathrm{K}(\mathrm{K} 0)$, pemberian $50 \mathrm{~kg} \mathrm{~K}$ sekaligus sebelum tanam (K1), pemberian $25 \mathrm{~kg}$ K sebelum tanam $+25 \mathrm{~kg} \mathrm{~K}$ saat 20 hari setelah tanam atau hst (K2), pemberian $100 \mathrm{~kg} \mathrm{~K}$ sekaligus sebelum secara manual (matun). Pengendalian hama dan penyakit dilakukan sesuai anjuran disesuaikan dengan kondisi di lapangan.

Peubah-peubah yang diamati meliputi tinggi tanaman, jumlah anakan, komponen hasil, hasil gabah, serapan $\mathrm{K}$, kandungan $\mathrm{K}$ dapat ditukar menjelang panen atau fase masak tanaman. Tinggi tanaman dan jumlah anakan diukur dari 16 rumpun setiap petak. Komponen hasil yang meliputi jumlah gabah total dan isi, dan bobot 1000 butir diukur 
dari 3 rumpun setiap petaknya. Hasil gabah kadar air 14 persen diukur dari ubinan ukuran $2 \mathrm{~m} \times 3 \mathrm{~m}$. Serapan K ditetapkan dari perkalian bobot tanaman dengan kandungan $\mathrm{K}$ total dalam tanaman. Kandungan $\mathrm{K}$ dapat ditukar ditetapkan menggunakan metode penjenuhan $\mathrm{NH}_{4} \mathrm{OAc} \mathrm{pH} 7$.

\section{HASIL DAN PEMBAHASAN}

\section{Hasil dan Pertumbuhan Padi Varietas Ciherang}

Pengembalian jerami padi ke dalam tanah nyata memberikan pertumbuhan tanaman padi terutama saat anakan maksimum dan menjelang dipanen, meskipun jumlah anakan produktif menjadi lebih rendah daripada tanpa pemberian jerami (Tabel 1). Dekomposisi jerami setelah anakan maksimum diduga menghasilkan asam-asam organik yang tidak menguntungkan atau menghambat pembentukan anakan produktif.

Pemberian kalium mutlak dibutuhkan tanaman padi sawah tadah hujan dalam pertumbuhannya. Peningkatan $\mathrm{K}$ tidak nyata meningkatkan pertumbuhan tanaman, tetapi dengan pemberian $50 \mathrm{~kg}$ $\mathrm{K} /$ ha telah memberikan pertumbuhan tanaman yang lebih baik dibandingkan tanpa kalium. Tanaman padi cenderung menyerap kalium berlebihan (luxury consumption), namun tidak memberikan kontribusi nyata terhadap hasil tanaman (Yoshida, 1981). Saat pemberian K tidak berpengaruh nyata terhadap pertumbuhan tanaman padi, dimana $\mathrm{K}$ diberikan sekaligus tidak berbeda nyata dengan $\mathrm{K}$ yang diberikan secara bertahap (Tabel 2).
Interaksi jerami padi dan kalium nyata meningkatkan hasil gabah padi Ciherang $(\mathrm{p}<0,05)$ dan persentase gabah isi $(\mathrm{p}<0,05)$, tetapi tidak berbeda nyata untuk jumlah gabah total dan bobot butir. Pengembalian jerami padi ke dalam tanah nyata memperbaiki hasil gabah $(\mathrm{p}<0,01)$ dengan kenaikan hasil gabah $0,7 \mathrm{t} / \mathrm{ha}$ dibandingkan tanpa jerami. Pemberian kalium nyata berpengaruh terhadap hasil gabah ( $p<0,01)$, namun peningkatan takaran kalium ataupun cara pemberiannya tidak berbeda nyata meningkatkan hasil gabah. Hasil gabah meningkat 0,93-1,39 t/ha dibandingkan tanpa pemberian kalium (Tabel 2). Serapan kalium oleh akar tanaman padi tetap berlangsung dengan pemberian kalium dalam dosis lebih tinggi namun tidak memberikan kontribusi nyata terhadap peningkatan hasil gabah (luxury consumption), selain potensi kehilangan kalium cukup tinggi melalui perlindian (Yoshida, 1981).

Pemberian kalium tidak nyata mempengaruhi jumlah gabah per malai tetapi nyata berpengaruh terhadap bobot butirnya. Pengembalian jerami ke dalam tanah berpengaruh nyata dalam meningkatkan jumlah gabah, tetapi tidak nyata meningkatkan persentase gabah isi dan bobot butir gabah (Tabel 2).

Tanah Vertic Endoaquept di lahan sawah tadah hujan di sepanjang pantai utara Jawa Tengah bagian timur mengandung kalium dapat ditukar rendah, sehingga kekahatan $\mathrm{K}$ sering menjadi penghambat pertumbuhan tanaman. Pada petakan

Tabel 2. Pertumbuhan padi Ciherang pada perlakuan jerami dan pupuk anorganik

\begin{tabular}{|c|c|c|c|c|}
\hline \multirow[b]{2}{*}{ Perlakuan } & \multicolumn{2}{|c|}{ Tinggi tanaman $(\mathrm{cm})$} & \multicolumn{2}{|c|}{ Jml anakan / rumpun } \\
\hline & $\begin{array}{c}\text { Anakan } \\
\text { aktif }\end{array}$ & Panen & $\begin{array}{c}\text { Maksi- } \\
\text { mum }\end{array}$ & $\begin{array}{l}\text { Produk- } \\
\text { tif }\end{array}$ \\
\hline \multicolumn{5}{|l|}{ Penggunaan jerami } \\
\hline Tanpa jerami (K0) & $61,1 \mathrm{a}$ & 84,6 b & $17,3 \mathrm{~b}$ & $14,2 \mathrm{a}$ \\
\hline Dengan jerami (K1) & $61,6 \mathrm{a}$ & 86,6 a & $19,1 \mathrm{a}$ & $12,9 \mathrm{~b}$ \\
\hline \multicolumn{5}{|l|}{ Pemberian pupuk anorganik } \\
\hline K0 : Tanpa K & $56,5 \mathrm{c}$ & $80,7 \mathrm{~b}$ & $17,3 \mathrm{~b}$ & $14,6 \mathrm{a}$ \\
\hline $\mathrm{K} 1: 50 \mathrm{~kg} \mathrm{~K}$ sebelum tanam & $60,2 \mathrm{~b}$ & 86,7 a & $18,0 \mathrm{ab}$ & $12,6 \mathrm{~b}$ \\
\hline $\mathrm{K} 2: 25 \mathrm{~kg} \mathrm{~K}$ sbl. tanam $+25 \mathrm{~kg}$ & $63,2 \mathrm{a}$ & 86,1 a & $18,9 \mathrm{ab}$ & $13,7 \mathrm{ab}$ \\
\hline $\mathrm{K}, 20 \mathrm{hst}$ & $63,9 \mathrm{a}$ & 87,3 a & $17,7 \mathrm{ab}$ & $13,3 \mathrm{ab}$ \\
\hline $\mathrm{K} 3: 100 \mathrm{~kg} \mathrm{~K}$ sbl. tanam & 63,2 a & 87,3 a & $19,1 \mathrm{a}$ & $13,7 \mathrm{ab}$ \\
\hline \multicolumn{5}{|l|}{$\begin{array}{l}\mathrm{K} 4: 50 \mathrm{~kg} \mathrm{~K} \text { sbl. tanam }+50 \mathrm{~kg} \\
\mathrm{~K}, 20 \mathrm{hst}\end{array}$} \\
\hline Koeftsien keragaman $(\%)$ & 8,23 & 9,11 & 6,72 & 7,88 \\
\hline
\end{tabular}

Angka selajur diikuti huruf sama tidak berbeda nyata pada taraf 0,05 menurut uji DMRT

sbl $=$ sebelum, hst $=$ hari setelah tanam 
tanpa perlakuan jerami dan tanpa pupuk kalium, pertumbuhan dan hasil gabah lebih rendah daripada petakan yang diberi jerami, pupuk kalium, dan kombinasi keduanya (Tabel 2). Kekahatan kalium dapat menyebabkan proses-proses metabolic dalamjaringan tanaman padi terhambat, antara lain produksi karbohidrat. Banyak enzim-enzim metabolic membutuhkan $\mathrm{K}+$ sebagai ko-faktor seperti dalam proses metabolisme protein dan metabolisme karbohidrat (Ma et al., 2012). sentase K menurun lambat laun menurut pertumbuhan tanaman, dan meningkat lagi pada fase berbunga hingga pengisian malai secara penuh.

Serapan K pada pemberian jerami umumnya lebih rendah daripada pada tanpa pemberian jerami. Dimungkinkan, jerami padi mengikat $\mathrm{K}$ sehingga menghambat laju serapan $\mathrm{K}$ oleh akar tanaman padi. Tanpa jerami, kalium efektif diserap tanaman sebelum K yang tersedia dalam tanah

Tabel 3. Hasil gabah dan komponen hasil padi Ciherang pada perlakuan jerami dan pupuk anorganik

\begin{tabular}{|c|c|c|c|c|}
\hline \multirow{2}{*}{ Perlakuan } & \multirow{2}{*}{$\begin{array}{c}\text { Hasil gabah } \\
\text { (t/ha) }\end{array}$} & \multicolumn{2}{|c|}{ Jumlah gabah / malai } & \multirow{2}{*}{$\begin{array}{c}\text { Bobot } 1000 \\
\text { butir }(\mathrm{g})\end{array}$} \\
\hline & & Total & Isi (\%) & \\
\hline \multicolumn{5}{|l|}{ Penggunaan jerami } \\
\hline Tanpa jerami (K0) & $5,82 \mathrm{~b}$ & $124,6 \mathrm{~b}$ & $72,1 \mathrm{a}$ & $24,28 \mathrm{a}$ \\
\hline Dengan jerami (K1) & $6,52 \mathrm{a}$ & $135,8 \mathrm{a}$ & $72,8 \mathrm{a}$ & 24,31 a \\
\hline \multicolumn{5}{|l|}{ Pemberian pupuk anorganik } \\
\hline K0 : Tanpa K & $5,25 \mathrm{~b}$ & $120,0 \mathrm{~b}$ & $69,6 \mathrm{~b}$ & $22,89 b$ \\
\hline $\mathrm{K} 1: 50 \mathrm{~kg} \mathrm{~K}$ sebelum tanam & $6,18 \mathrm{a}$ & $134,4 \mathrm{a}$ & $70,4 \mathrm{ab}$ & $24,37 \mathrm{ab}$ \\
\hline $\begin{array}{c}\mathrm{K} 2: 25 \mathrm{~kg} \mathrm{~K} \text { sbl. tanam }+25 \\
\text { kg K, } 20 \text { hst }\end{array}$ & $6,33 \mathrm{a}$ & $130,2 \mathrm{ab}$ & $72,7 \mathrm{ab}$ & $24,93 \mathrm{a}$ \\
\hline $\mathrm{K} 3: 100 \mathrm{~kg} \mathrm{~K}$ sbl. tanam & $6,64 \mathrm{a}$ & $132,8 \mathrm{a}$ & $75,0 \mathrm{a}$ & $25,09 \mathrm{a}$ \\
\hline $\begin{array}{c}\mathrm{K} 4: 50 \mathrm{~kg} \text { K sbl. tanam }+50 \\
\text { kg K, } 20 \text { hst }\end{array}$ & $6,47 \mathrm{a}$ & $133,4 \mathrm{a}$ & $74,4 \mathrm{a}$ & $24,20 \mathrm{ab}$ \\
\hline Koefisien keragaman $(\%)$ & 8,31 & 7,32 & 5,03 & 7,34 \\
\hline
\end{tabular}

\section{Serapan Kalium Tanaman}

Peningkatan serapan K oleh tanaman padi terjadi seiring dengan bertambahnya umur tanaman atau fase pertumbuhan tanaman. Peningkatan tajam serapan $\mathrm{K}$ terjadi setelah tanaman berumur 60 hari setelah tumbuh (hst). Puncak serapan K terjadi saat tanaman berumur 80 hst baik dengan atau tanpa pemberian jerami, dan mengalami penurunan saat pengisian malai hingga fase pemasakan atau menjelang panen (Gambar 1). Serapan K saat 80 hst pada perlakuan tanpa jerami lebih tinggi daripada pada perlakuan dengan jerami. Peningkatan serapan $\mathrm{K}$ tanaman terjadi akibat peningkatan biomassa tanaman.Laju produksi biomassa tanaman padi proporsional dengan kandungan mineral setiap bagian tanaman sebagai hasil perubahan status fisiologi tanaman dengan perkembangan fase pertumbuhan dan kondisi lingkungan seperti ketersediaan hara dalam tanah selama pertumbuhannya (De Datta, 1981). Per- tercuci ke lapisan tanah yang lebih dalam. Kalium yang mengatur berbagai proses metabolisme diserap dengan laju hampir setara dengan produksi biomassa. Namun tidak ada translokasi nyata dari unsur K organ vegetatif ke gabah selama tahap pengisian malai. Menurut De Datta (1981), sintesis protein aktif selama fase vegetatif, sintesis bahan dinding sel seperti selulose, lignin menjadi aktif selama fase reproduktif walaupun sintesis protein juga berlangsung. Sintesis pati dalam gabah adalah lebih aktif selama fase pemasakan (Yoshida, 1981).

\section{Perubahan Kalium dapat ditukar dalam tanah}

Pemberian masukan berupa jerami dan pupuk kalium berpengaruh terhadap ketersediaan kalium dalam tanah. Pemberian pupuk K meningkatkan kalium dapat ditukar dalam tanah. Tanpa pemberian jerami, kalium dapat ditukar pada lapisan tanah atas $(0-15 \mathrm{~cm})$ lebih rendah daripada pada 


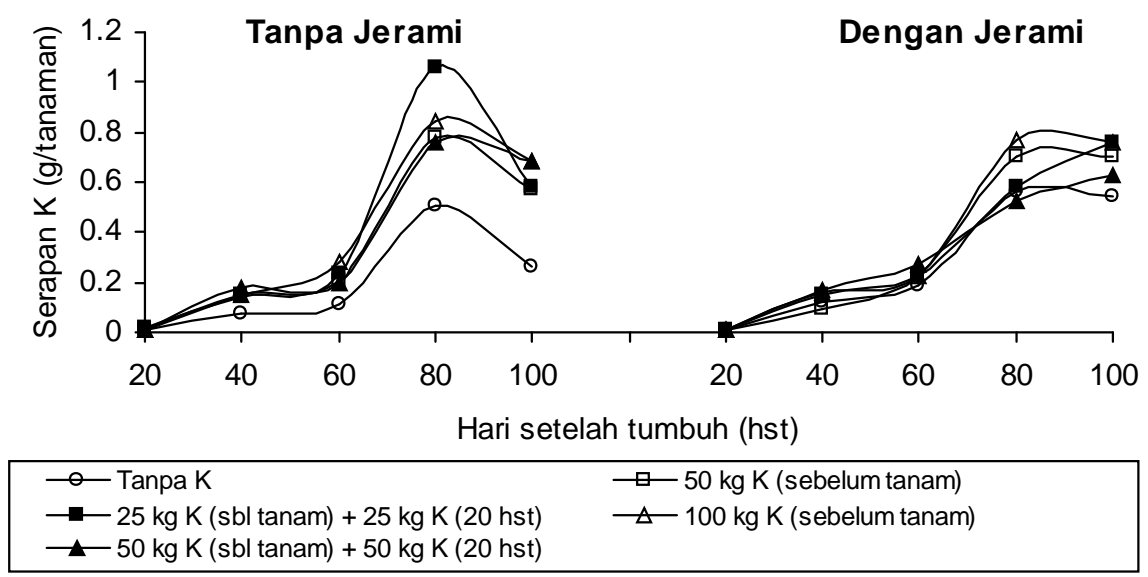

Gambar 1. Pola serapan kalium padi sawah tadah hujan pada perlakuan jerami dan pupuk kalium, Jakenan

lapisan tanah di bawahnya $(16-30 \mathrm{~cm})$. Sebaliknya, kalium dapat ditukar pada lapisan tanah atas lebih tinggi daripada pada lapisan tanah di bawahnya dengan pemberian jerami (Gambar 2). Potensi kalium tercuci ke lapisan tanah yang lebih dalam lebih besar terjadi bilamana tidak ada bahan pengikat kalium seperti bahan organik. Dengan pemberian bahan organik seperti jerami padi, maka pencucian kalium dapat ditekan karena kalium akan diikat oleh bahan organik untuk sementara waktu.

Kalium diserap tanaman dalam bentuk $\mathrm{K}^{+}$baik yang terdapat pada larutan tanah maupun dalam tapak pertukaran. Peningkatan kalium dapat ditukar dalam tanah dengan pemberian pupuk $\mathrm{K}$ anorganik dan jerami padi dapat memperbaiki status keharaan kalium bagi pertumbuhan tanaman. Ketersediaan kalium dalam tanah dipengaruhi oleh kondisi kelengasan di sekitar perakaran tanaman padi (rizosfer). Pada tanah tergenang atau kondisi anaerobik, proses-proses utama terjadi di zona perakaran padi yang mempengaruhi mobilitas kalium, yaitu (1) pelepasan $\mathrm{O}_{2}$ dari akar menyebabkan oksidasi ion fero $\mathrm{Fe}^{2+}$ akibat reduksi tanah atau terjadi asidifikasi dengan persamaan reaksi $4 \mathrm{Fe}^{2+}+\mathrm{O}_{2}+$ $10 \mathrm{H}_{2} \mathrm{O} \rightarrow 4 \mathrm{Fe}(\mathrm{OH})_{3}+8 \mathrm{H}^{+}$, (2) pelepasan $\mathrm{H}^{+}$ dari akar padi untuk menyeimbangkan serapan kation-anion untuk mempertahankan netralitas listrik sepanjang kontak akar-tanah, dan (3) perubahan $\mathrm{pH}$ tanah sebagai hasil akar melepaskan $\mathrm{CO}_{2}$ (Dobermann dan Fairhurts, 2000). Perubahan dalam perakaran tersebut terjadi sebagai akibat pertumbuhan padi pada tanah tergenang dan mempengaruhi kelarutan dan mobilitas hara-hara dan bahan toksin. Asidifikasi dalam rizosfer mengakibatkan peningkatan kelarutan P dan Zn, menurunkan mobilitas kation,

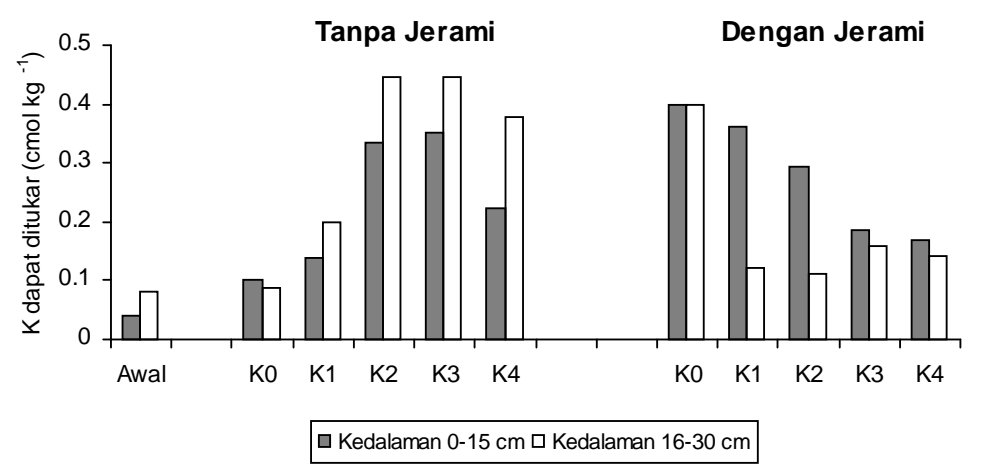

Gambar 2. Perubahan kalium dapat ditukar dalam tanah menjelang tanaman dipanen K0: tanpa K, K: pemberian $50 \mathrm{~kg} \mathrm{~K}$ sekaligus sebelum tanam, K2: pemberian $25 \mathrm{~kg} \mathrm{~K}$ sebelum tanam $+25 \mathrm{~kg}$ K saat 20 hari setelah tanam atau hst, K3: pemberian $100 \mathrm{~kg} \mathrm{~K}$ sekaligus sebelum tanam, K4: pemberian $50 \mathrm{~kg} \mathrm{~K}$ sebelum tanam $+50 \mathrm{~kg}$ K saat $20 \mathrm{hst}$ 


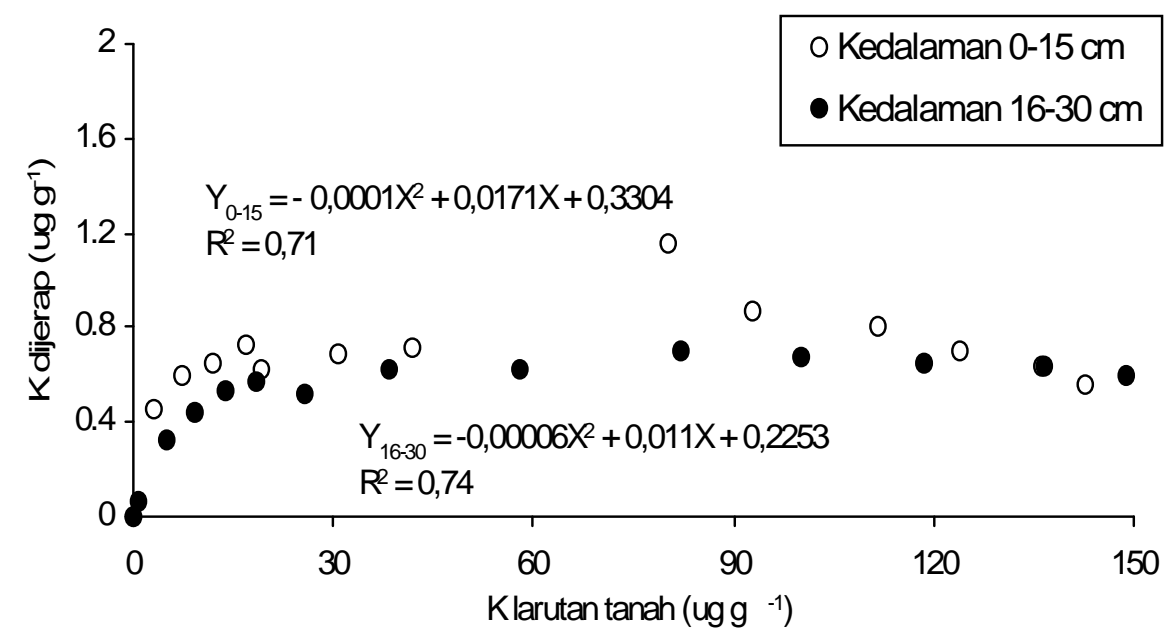

Gambar3. Hubungan antara $\mathrm{K}$ dalam larutan tanah dan $\mathrm{K}$ dijerap pada tanah Vertic Endoaquept dari Jakenan, Pati, Jawa Tengah

peningkatan pelepasan $\mathrm{K}$ tidak dapat ditukar. Asidifikasi di sekitar perakaran terjadi pergantian Koleh $\mathrm{H}^{+}$di kisi-kisi liat (Wihardjaka et al., 1999).

Tanah Vertic Endoaquepts Jakenan mempunyai kemampuan menjerap kalium rendah. Hubungan kuadratik antara K terjerap dan K dalam larutan tanah terlihat pada Gambar 3. Peningkatan kalium dalam larutan tanah hingga konsentrasi $90 \mu \mathrm{g} \mathrm{g}^{-1}$, kalium terjerap cenderung menurun (Gambar 3). Peningkatan tajam kalium terjerap terjadi pada konsentrasi $\mathrm{K}$ dalam larutan tanah kurang dari $30 \mu \mathrm{g} \mathrm{g}^{-1}$. Semakin dalam lapisan tanah, kemampuan tanah menjerap kalium lebih rendah daripada lapisan olah tanah. Pada kondisi anaerobik, K-dd digantikan dari tapak pertukaran kation ke dalam larutan tanah akibat kompetisi dengan $\mathrm{Mn}^{2+}$ dan $\mathrm{Fe}^{2+}$. Ini memungkinkan konsentrasi K-larutan mempertinggi difusi $\mathrm{K}$ ke akar-akar padi, terutama pada tanah dengan potensi fiksasi $\mathrm{K}$ kecil seperti tanah kaolinitik yang didominasi liat tipe 1:1. Namun besarnya konsentrasi K dalam larutan tanah mungkin mengakibatkan kehilangan $\mathrm{K}$ akibat pencucian pada tanah bertekstur kasar atau tanah dengan laju perkolasi tinggi $(>10 \mathrm{~mm} /$ hari) (Dobermann dan Fairhurts, 2000).

\section{KESIMPULAN}

1 Interaksi jerami dan kalium nyata meningkatkan hasil gabah, dimana jerami berperan meningkatkan efisiensi pemupukan kalium.

2 Peningkatan takaran pupuk kalium dan cara pemberiannya tidak nyata berpengaruh terhadap hasil gabah padi Ciherang.
3 Puncak serapan K tanaman terjadi saat fase pertumbuhan keluar malai, dan mengalami penurunan saat pengisian malai hingga fase pemasakan tanaman.

4 Kandungan kalium dapat ditukar dalam tanah dipengaruhi oleh masukan pupuk K anorganik dan jerami padi. Tanpa jerami padi, $\mathrm{K}$ dapat ditukar pada lapisan tanah atas lebih rendah daripada pada lapisan tanah dibawahnya. Namun dengan pemberian jerami, kandungan $\mathrm{K}$ dapat ditukar lebih tinggi terjadi pada lapisan tanah atas.

5 Pemberian jerami padi dapat mengurangi kehilangan $\mathrm{K}$ akibat pencucian.

\section{DAFTAR PUSTAKA}

De Datta, S.K. 1981. Principles and Practices of Rice Production. John Wiley \& Sons, Inc. New York.

Dobermann, A., and Fairhurst, T. 2000. Rice: Nutrient Disorder \& Nutrient Management. Potash and Phosphate Institute of Canada and International Rice Research Institute.

Karama, A.S., Sri Adiningsih, J., Supartini, M., Sediarso, M., Kasno, A., dan Prihatini, T. 1992. Peranan pupuk kalium dalam peningkatan produktivitas lahan pertanian di Indonesia. p. 9-48 dalam Peranan Kalium dalam Pemupukan Berimbang untuk Mempercepat Swasembada Pangan. Prosiding Seminar Nasional Kalium. Jakarta, 4 Agustus 1992. 
Ma,T.L., W.H. Wu, and Y.Wang. 2012.Transcriptome analysis of rice root response to potassium deficiency. BMC Plant Biology 12: 161169.

Odjak, M. 1992. Effect of potassium fertilizer in increasing quality and quantity of crop yield.p. 94-104 dalam Prosiding Seminar Nasional Kalium 4 Agustus 1992. Ditjen Pertanian Tanaman Pangan. Jakarta.

Ranamukhaarachi, S.L., and W.M. Ratnayake. 2006. The effect of straw, stubble, and potassium on grain yield of rice in rice-rice cropping systems in the mid-country wet zone of Srilanka. Science Asia 32: 151-158.

Saha, P.K., M.A.M., A.T.M.S. Hossain, F. Rahman, and M.A. Saleque. 2009. Contribution of rice straw to potassium supply in rice-fallow-rice cropping pattern. Bangladesh J. Agril. Res. 34(4): 633-643.

Sekhon, G.S. 1995. Characterization of $K$ availability in soils of subtropical (humid) regions of China. p. 115-134. Proceedings of the $24^{\text {th }}$ Colloquium of the IPI held at Chiang May/Thailand, Basel, Switzerland.

Sri Rochayati, Mulyadi, dan Sri Adiningsih, J. 1990. Penelitian efisiensi penggunaan pupuk di lahan sawah. Makalah dipresentasikan dalam Lokakarya Nasional Efisiensi Penggunaan Pupuk V. Cisarua, 12-13 November 1990. Bogor.
Suparyono, Kartaatmadja, S., and Fagi, A.M. 1992. Relationship between potassium and development of several major rice diseases. p. 155-162 dalam Peranan Kalium dalam Pemupukan Berimbang untukMempercepat Swasembada Pangan. Prosiding Seminar Nasional Kalium. Jakarta, 4 Agustus 1992.

Wade, L.J. 1998. Nutrient research on rainfed lowland rice in relation to the 1995 review. p. 29 - 40 in Ladha, J.K., Wade, L., Dobermann, A., Reichardt, W., Kirk, G.J.D., and Piggi, C. (Eds.). Rainfed Lowland Rice: Advances in Nutrient Management Research. International Rice Research Institute. Los Banos, Philippines.

Wihardjaka, A., G.J.D. Kirk, S. Abdurachman, \& C.P. Mamaril. 1999. Potassium Balances in Rainfed Lowland Rice on Light Textured Soil. Field Crop Res. 64: 237 - 247.

Yoshida, S. 1981. Fundamentals of Rice Crop Science. International Rice Research Institute. Los Banos, Philippines. 